\title{
Multirresistência bacteriana e a consequência do uso irracional dos antibióticos
}

Este estudo objetiva realizar uma discussão a respeito da natureza/estrutura das bactérias e de como elas desenvolvem algumas formas de resistência a medicamentos, as quais são adquiridas ao longo do tempo ou por fatores de ameaças. Para tanto, apresentamos uma síntese de resultados adquiridos por meio de uma revisão sistemática de bibliografia relativa à temática investigada, problematizando como o mau uso de antibióticos, assim como o tratamento empírico, tornam-se os principais fatores que desencadeiam a resistência bacteriana, apontando também para as várias formas de resistências desenvolvidas pelas bactérias e a prevenção a partir da atenção farmacêutica e do uso racional dos antibióticos.

\section{Bacterial multidrug resistance and the consequence of irrational antibiotic use}

This study aims to discuss the nature / structure of bacteria and how they develop some forms of drug resistance, which are acquired over time or by threat factors. To this end, we present a synthesis of results acquired through a systematic literature review on the investigated theme, discussing how the misuse of antibiotics, as well as the empirical treatment, become the main factors that trigger bacterial resistance, also pointing out for the various forms of resistance developed by bacteria and prevention from pharmaceutical attention and rational use of antibiotics.

Keywords: Antibiotic; Anti-infectives; Drug resistance; Streptomycin.

Topic: Microbiologia

Reviewed anonymously in the process of blind peer.

Faculdade Natalense de Ensino e Cultura, Brasil

http://lattes.cnpq.br/4134152465913204

adrianomenino2016@gmail.com

d

DOI: 10.6008/CBPC2236-9600.2019.002.0001
Received: 02/03/2019

Approved: 03/05/2019
Referencing this:

MACEDO JÚNIOR, A. M.. Multirresistência bacteriana e a

consequência do uso irracional dos antibióticos. Scire Salutis, v.9, n.2, p.1-8, 2019. DOI: http://doi.org/10.6008/CBPC2236$\underline{9600.2019 .002 .0001}$ 


\section{INTRODUÇÃO}

Os antimicrobianos reduziram grande taxa de mobilidade e mortalidade global causada por infecções bacterianas, visto que esses fármacos são revolucionários no tratamento bactericida. No entanto, nas últimas décadas, o aumento nos casos de resistência microbiana a antibióticos tem aumentado bastante, alertando os profissionais de saúde e a comunidade científica. Consoante, observam Caumo et al. (2010), como estratégia de combate a essa resistência, até o ano de 2004, apenas a linezolida e daptomicina foram aprovados pela FDA, constituindo-se como antibióticos com mecanismo de ação diferente.

As infecções multirresistentes normalmente são causadas pela prescrição precoce do antibiótico feita com base em dados epidemiológicos, e não no diagnóstico laboratorial, o que leva a resistência desse microrganismo (KADOSAKI et al., 2012). No contexto hospitalar, a resistência bacteriana tem ocorrido pelo alto consumo de forma abusiva dos antibióticos, dificultando o tratamento das infecções (KADOSAKI et al., 2012).

As bactérias possuem 4 principais mecanismo que as levam a resistir ao efeito do antibiótico: produzem enzimas nas quais catalisam a ação do fármaco, o que acontece quando as bactérias produzem a $\beta$-lacmase que vai degradar a ação de beta-lactamicos; a bactéria vai codificar a estrutura alvo do antibiótico produzindo e substituindo por uma nova mais resistente, temos o exemplo da mutação ribossomal $30 \mathrm{~S}$ que será resistente a estreptomicina; algumas bactérias são intracelulares, reduzindo a permeabilidade de sua membrana e dificultando a entrada do fármaco, nesse caso a penicilina pode ou não atravessar as porinas; este mecanismo consiste em expelir o fármaco de dentro para fora como um espécie de bomba de resistência a múltiplos fármacos (LEVISON, 2011).

De acordo com uma pesquisa mencionada na Revista Brasileira de Anestesiologia, em artigo intitulado 'Colonização bacteriana por causa do aumento da carga de trabalho da equipe enfermagem em unidade de terapia intensiva', verificou-se, em uma unidade de terapia intensiva na Turquia, uma sobrecarga de trabalho da equipe de enfermagem que contribuía para epidemia de infecções nosocomiais. No mesmo texto, afirma-se que a exposição do paciente a muitos dias de internação contribui para a colonização e desenvolvimento de infecção multirresistente pelos agentes citados na obra. Nesse caso deveriam dispor de mais tempo em cuidados com paciente colonizados por bactérias multirresistentes gram-positivas do que com aqueles pacientes com bactérias multirresistentes gram-negativos.

Com o intuito de erradicar as altas taxas de colonização e infecção nosocominal por bactérias resistentes deve ser levado em conta os fatores que implicam na ação, tempo prolongado de internação do paciente, falta de mais profissionais na equipe para reduzir excesso de trabalho dos enfermeiros, a quantidade exata de enfermeiros por ala hospitalar, responsáveis por diminuir concomitantemente os riscos para desenvolvimento de infecções nosocomiais (AYCAN et al., 2015).

Segundo Caraça et al. (2016), o Staphylococcus aureus tem elevada repetição nas comunidades e nos hospitais e sua alta patogenicidade em causar doenças. As cepas de Staphylococcus aureus meticilina resistentes (MRSA), a diversos antibióticos, têm aumentado o número de infecções hospitalares. Conforme 
Vasconcelos et al. (2010), em um estudo realizado num açude localizado em Santo Anastácio (CE), mostrouse que as águas desse açude disseminam estirpes de Escherichia coli, com forte indício de resistência a inúmeros antimicrobianos, principalmente à tetraciclina, o que leva a adotar métodos de controle semeando os genes de resistência.

Em Itabuna (BA), uma pesquisa realizada na comercialização da água de coco mostrou que o produto estava inapropriado para o consumo, revelando problemas relacionados à higienização. Das amostras de água de coco coletadas, foram isolados 5 microrganismos de staphylococcus aureus e outros pertencentes a família das enterobactérias. Dos encontrados, três foram resistentes a no mínimo 5 antimicrobianos de três classes diferentes (CARVALHO et al., 2012).

\section{METODOLOGIA}

Considerando-se a metodologia da presente pesquisa, se trata de uma pesquisa exploratória, a qual é uma preparação para a pesquisa explicativa. Assim, tal modalidade de pesquisa visa a revelação de informações concernentes a determinado objeto, sendo restrito o campo de trabalho, com observância para a maneira através da qual efetiva-se a pronúncia do referido elemento. Desta feita, promoveu-se uma revisão de literatura, materializada por vias de publicações contidas em periódicos, empregando-se os descritores Antibiótico, Anti-Infecciosos, Resistência a Medicamentos e Estreptomicina. Consistiu no método de abordagem como qualitativo.

\section{RESULTADOS E DISCUSSÃO}

\section{Estrutura da parede celular procariótica}

As bactérias são diferenciadas entre si pela composição química, estrutura e espessura da parede celular, sendo divididas entre bactérias gram-positivas e gram-negativas. A parede celular é composta por uma camada peptideoglicano e fica externa a membrana plasmática, a qual nas gram-positivas são mais espessas e apresenta fibras de ácido teicóico que se projetam exterior ao peptideoglicano. Nas gramnegativas, a camada é mais complexa, sendo constituída por polissacarídeos, fosfolipídeos e lipoproteínas que ficam entre a membrana externa e a citoplasmática da célula bacteriana (figura 1) (LEVISON, 2011).

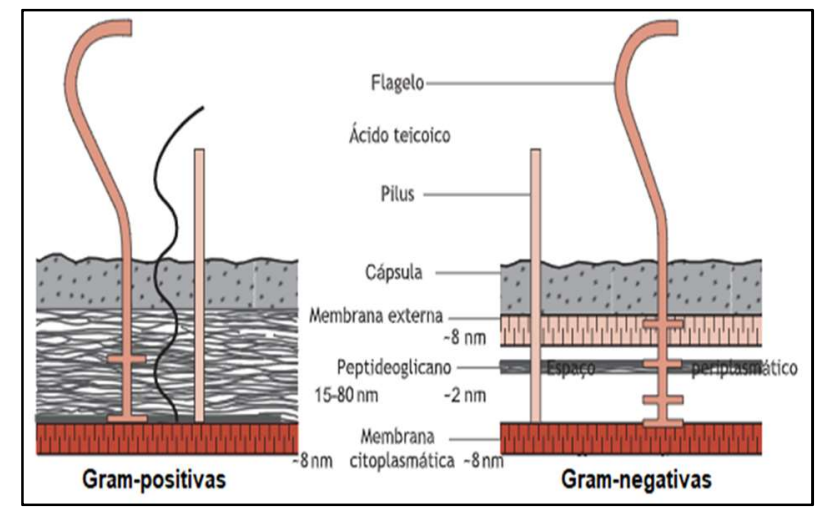

Figura 1: Bactérias gram-positivas e gram-negativas. Fonte: Levison (2011). 


\section{Mecanismo genético de resistência bacteriana}

A resistência bacteriana aos fármacos existentes está ligada a modificações nas informações genéticas do microrganismo, intermediadas por mutação cromossomal, adesão de um plasmídeo ou até mesmo um transposon, as bactérias se reproduzem por bipartição, fazendo rapidamente sua colônia, através de múltiplas divisões mitóticas as novas bactérias geradas podem adquirir esse mecanismo de resistência. (LEVINSON, 2011).

\section{Resistência cromossomal}

A mutação cromossomal é causada por um gene que permite que o microrganismo codifique o alvo do fármaco ou a permeabilidade da membrana que contém a entrada do fármaco. Desta forma, essa mutação ingênua é clinicamente menor se comparada a mutações mediadas por resistências de plasmídeos. Nesse caso, o tratamento combinado de dois ou mais antibióticos é resultado de uma probabilidade na qual a bactéria tem de sofrer uma mutação tornando-a mais resistente. Essa combinação de antibióticos possibilita um efeito quase nulo de resistência, visto que através do mecanismo de ação de cada um dos fármacos chega-se a resolução da doença: se o determinado antibiótico A não tratar a infecção a uma assertiva considerável de que o antibiótico B será eficaz para a resolução da infecção, incapacitando o microrganismo de se tornar resistente (LEVISON, 2011).

\section{Resistência mediada por plasmídeos}

Os plasmídeos são moléculas de DNA encontrados no citoplasma bacteriano, são compostos por uma fita dupla extracromossomal que se autorreplica, seus genes conferem benefícios que codificam a célula para resistir a metais pesados e antibióticos (MOREIRA et al., 2013). Levison (2011) também destaca uma preocupação com esse tipo de mutação, por ocorrer em vários microrganismos diferentes, os quais continuamente interferem na resistência a múltiplos fármacos e a alta migração de genes de uma célula para outra por meio de conjugação. Os fatores de resistência implicam na transferência de genes resistentes a antibióticos nas células hospedeiras, já os fatores determinantes de resistência conferem a célula bacteriana a produção de enzimas que degradam os fármacos ou agentes tóxicos (TORTORA et al., 2012).

\section{Resistência Intermediada por transposon}

Os transposon são genes que possuem a capacidade de se transportar do interior de um segmento de DNA para outro, através do gene transposase que se localiza no cromossomo bacteriano ou plasmídeo. Nesse processo, a transposase é a enzima responsável por catalisar a clivagem e a remontagem do DNA que ocorrem na transposição. Transposons simples são entitulados sequências de inserção (SI), que contém apenas um gene codificante da transposase e de sítios de reconhecimento (MOREIRA et al., 2013).

Consonante afirma Tortora et al. (2012), transposons complexos também podem conduzir genes não conectados ao processo de transposição, na qual os tranposons contém genes de resistência a antibióticos. 
Os transposons tem ilimitado mecanismo para movimentar genes de um determinado cromossomo para outro. De acordo com o mesmo autor, a resistência à vancomicina foi passada de Enterococcus faecalis para Staphylococcus aureus via um transposon denominado Tn1546, contudo esse mecanismo garante a evolução dos organismos.

\section{Mecanismo específico de resistência bacteriana a antibióticos}

Nas últimas décadas, os tratamentos por agentes antimicrobianos revolucionaram a medicina, o que reduziu consideravelmente a mortalidade humana. Todavia, o uso indiscriminado dos antibióticos levou as bactérias a desenvolverem mecanismos de defesas contra os fármacos. O controle da resistência e exames de sensibilidade das bactérias infecciosas escapam de erros terapêuticos e de resistência bacteriana ocasionado pelo uso desorientado do antimicrobiano (OLIVEIRA et al., 2014). O surgimento de uma infecção bacteriana resistente reduz as opções de fármacos efetivos no tratamento, agravando o quadro clínico do paciente já hospitalizado, aumentando o seu tempo de internação o que eleva os custos durante a sua recuperação, além de ele ficar exposto a outros tipos de infecções hospitalares (COSTA et al., 2017).

As bactérias possuem um conjunto de componentes que as integram e potencializam a sua resistência e proteção contra agentes químicos. A exemplo disso, o peptideoglicano das bactérias gramnegativas é menos espesso e possuem membrana externa formada por uma bicamada de lipopolissacarídiofosfolipídica o que dificulta a entrada de moléculas em seu interior, diferentemente das gram-positivas essas bactérias possuem seu peptideoglicano bem mais espesso e são mais sensíveis a antibióticos por não apresentarem membrana externa (CAUMO et al., 2010).

A resistência bacteriana pode decorrer do uso indevido de um antibiótico para tratar de uma infecção para a qual não seja específico para o determinado sítio de atuação do microrganismo. Para exemplificar, temos Mycoplasma pneumoniae, o qual tem parede celular de peptideoglicano ausente, se for escolhido um tratamento com inibidores de betalactâmicos da síntese de parede celular, ocasiona naturalmente sua resistência. (OLIVEIRA et al., 2014).

\section{Sobre a desativação do antimicrobiano}

A desativação do antimicrobiano é uma forma de resistência e ocorre desativando o fármaco, na qual a bactéria produz enzimas que degradam o antimicrobiano (COSTA et al., 2017). Podemos destacar o principal exemplo desse mecanismo a partir da produção da enzima $\beta$-lactamase que degrada o anel $\beta$ lactâmico das penicilinas e cefalosporinas (COSTA et al., 2017). O staphylococcus aureus resistente à meticilina (MRSA) possui em seu mecanismo a produção de uma proteína que se conecta à penicilina (PBPs) anormal, titulado PBP 2a ou PBP2, que não se identifica com os $\beta$-lactâmicos, o que faz o antimicrobiano perder sua efetividade (CARAÇA et al., 2016).

As $\beta$-lactamases reguladas por plasmídeos apresentam três grupos: oxacilinases, que degradam penicilinas e oxacilinas; carbenicilinases, que degradam penicilinas e carbenicilinas; e por último as betalactamases de elevado espectro que desativam penicilinas e cefalosporinas de $3^{\circ}$ geração (MOREIRA et al., 
2013). Diversas bactérias gram-positivas e gram-negativas possuem seu espectro beta-lactamase ampliado através de codificações por genes plasmidiais como o CTX-M, que dão resistência às penicilinas e às cefalosporinas de $3^{\circ}$ geração (COSTA et al., 2017), consoante afirma LOREIRO et al. (2016), observando que o MRSA adquiriu seu mecanismo de resistência através da alteração do alvo do antimicrobiano.

\section{Transfiguração do alvo antimicrobiano}

Através da transfiguração do alvo o microrganismo codifica uma nova substância resistente ao antimicrobiano, por um gene adquirido que vai substituir o alvo no qual o antibiótico terá efeito, a bactéria pode possuir uma via bioquímica alternativa que desvia a reação particular que é inibida pelo antibiótico da célula (MOREIRA et al., 2013). Na sequência, a bactéria continua produzindo seu alvo legítimo por meio desse modo (LOREIRO et al., 2016).

\section{Efluxo do antimicrobiano}

Trata-se de um mecanismo não especifico para as diversas classes bacterianas, que protege a célula dos procarióticos através de proteínas membranares que carregam o antimicrobiano do meio intracelular até o extracelular antes que a droga possa se tornar efetiva (CAUMO et al., 2010). Esse aparato de resistência alcança todas as classes de antibacterianos principalmente os macrólitos, tetraciclinas e fluoroquinolonas, podendo ser encontrado bactérias gram-positivas bem como gram-negativas.

\section{Modificação da membrana em sua permeabilidade e a consequência do mau uso dos antimicrobianos}

As bactérias gram-negativas são relativamente mais resistentes do que as gram-positivas devido ao fato de sua parede celular possuir porinas, que são proteínas que agem bloqueando a entrada de moléculas no meio intracelular tornando o antibiótico ineficaz em sua ação (TORTORA et al., 2012). A automedicação é a prática de utilizar medicamentos sem prescrição médica, se baseando em crenças populares ou prescrições anteriores (MORAES et al.,2016).

O uso irracional dos antibióticos tem conexão com crescimento de bactérias resistentes com a criação de novos fármacos antimicrobianos, uma vez que o consumo descontrolado desses medicamentos aumenta a taxa de resistência bacteriana (FRANCO et al., 2015). Os antibacterianos têm ação bacteriostática (inibindo a reprodução ou aumento das bactérias) ou bactericida (eliminando toda a forma de vida bacteriana), de modo integral são classificados como antibióticos, quimioterápicos e semissintéticos (TRAVASSOS et al., 2010).

A automedicação é em grande parte causadora da resistência bacteriana, é um problema de saúde pública que eleva as hospitalizações e contágios por bactérias (OLIVEIRA et al., 2010). De acordo com Paim et al. (2014), foi realizada uma pesquisa analisando a periodicidade de fenótipos de resistência em um hospital no qual os autores constataram que $58 \%$ dos isolados eram resistente à cefalosporina de terceira geração, indicando controle no tratamento empírico dos antibacterianos e cautela e domínio das infecções 
hospitalares, aponta também que em outro estudo $90 \%$ dos casos isolados apareceram com cepas de pseudômonas aeruginosa resistentes a cefalosporinas de terceiras geração.

Assim, o uso racional dos antibióticos deve obedecer a critérios como a utilidade do fármaco, prescrição correta, seleção correta do medicamento de acordo com o estado de saúde do paciente, informando a dose, posologia e duração do tratamento (GOLL et al., 2014). A consequência da automedicação está ligada a não adesão do tratamento por completo, uma vez que o médico não instrui o paciente por completo da terapia, não solicita exames laboratoriais que são eficazes no resultado do diagnóstico, decorrendo na consequência de que, assim que passado os sintomas, o medicamento seja suspenso pelo próprio paciente (MORAES et al., 2016). Essa carência nos recursos de diagnósticos laboratoriais faz com que o médico aplique o tratamento empírico e muitas vezes o antibiótico entra em desuso para aquela determinada necessidade (OLIVEIRA et al., 2010).

\section{CONCLUSÕES}

A pesquisa em tela demonstra que, mesmo com o avanço da ciência em formas de combater graves infecções bacterianas, há um novo desafio sendo vivenciado relativo ao mau uso dos antibióticos. Tem-se observado que não raro as bactérias tornam-se multirresistentes a antibióticos geneticamente modificandose. Esse fato decorre principalmente em consideração ao mau uso dos antibióticos, que ocorre em virtude da descontinuação da terapia, tratamentos empíricos e não laboratoriais, e escassez de condições sanitárias em algumas regiões do mundo. Como consequência, em virtude do que foi mencionado, estima-se que uma nova era se aproxima na qual até o ano de 2050 a humanidade pode ser erradicada por microrganismos resistentes em decorrência da forma errônea de como alguns medicamentos são usados.

\section{REFERÊNCIAS}

ALVES, L. N. S.; OLIVEIRA, C. R.; SILVA, L. A. P.; GERVÁSIO, S. M. D.; ALVES, S. R.; SGAVIOLI, G. M.. Hemoculturas: estudo da prevalência dos microrganismos e o perfil de sensibilidade dos antibióticos utilizados em unidade de terapia intensiva. Journal of the Health Science Institute, v.30, n.1, p.44-47, 2012.

AYCAN, I. O.; CELEN, M. K.; YILMAZ, A.; ALMAZ, M. S.; DAL, T.; CELIK, Y.; BOLAT, E.. Colonização bacteriana por causa do aumento da carga de trabalho da equipe de enfermagem em unidade de terapia intensiva. Revista Brasileira de Anestesiologia, v.65, n.1, p.180-185, 2015.

BARBOSA, A. C. N.; SOUZA, M. A.; VILAR, M. S. A.; VILAR, D. A.; VELOSO, M. F. L.; SILVA, A. L. R.. Avaliação microbiológica de artigos de uso médico numa unidade de terapia intensiva. Tema, v.11, n.16, 2011.

BRITO, M. A.; CORDEIRO, B. C.. Necessidades de novos antibióticos. Jornal Brasileiro de Patologia e Medicina Laboratorial, Rio de Janeiro, v.48, n.4, p.247-249, 2012.

CALMO, K.; DUARTE, M.; CARGNIN, S. T.; RIBEIRO, V. B.; TASCA, T.; MACEDO A. J.. Resistencia bacteriana no meio ambiente e implicações na clínica hospitalar. Liberato, Novo Hamburgo, v.11, n.16, p.89, 2010.

CARACA, B. A. A.; SISTI, E.. A relevância do staphylococcus aureus resistente à meticilina (mrsa) nas infecções hospitalares. Revista Interdisciplinar de Ensino, Pesquisa e Extensão, v.4, n.1, 2016.

CARVALHO, L. R.; PINHEIRO, B. E. C.; PEREIRA, S. R.; BORGES, M. A. S. F.; MAGALHAES, J. T.. Bactérias resistentes e antimicrobianos em amostras de água de coco comercializada em Itabuna, Bahia. Revista Baiana de Saúde Pública, v.36, n.3, p.751-763, 2012.

COSTA, A. L. P.; SILVA JUNIOR A. C. S.. Resistência bacteriana aos antibióticos e saúde pública: uma breve revisão de literatura. Estação Científica, Macapá, v.7, n.2, p.45-57, 2017.

DIAS, M.; MONTEIRO, M. S.; MENEZES, M. F.. Antibióticos e resistência bacteriana, velhas questões, novos desafios. Cadernos de Otorrinolaringologia, v.1, n.10, 2010.

FRANCO, J. M. P. L.; MENDES, R. C.; CABRAL, F. R. F.; MENEZES, C. D. A.. O papel do farmacêutico frente à 
resistência bacteriana ocasionada pelo uso irracional de antimicrobianos. Semana Acadêmica, Fortaleza, v.1, n.72, p.1-17, 2015.

GOLL, A. S., FARIA, M. G. I.. Resistência bacteriana como consequência do uso inadequado de antibióticos. Infarma, v.5, n.1, p.69-72, 2014

GRILLO, V. T. R. S.; GONÇALVES, T. G.; CAMPOS JUNIOR, J. C.; PANIÁGUA, N. C.; TELES, C. B. G.. Incidência bacteriana e perfil de resistência a antimicrobianos em pacientes pediátricos de um hospital público de Rondônia, Brasil. Revista de Ciências Farmacêuticas Básica e Aplicada, v.34, n.1, p.117-123, 2013.

GUIMARÃES, O. D.; MOMESSO, L. S.; PUPO, M. T.. Antibióticos: importância terapêutica e perspectivas para a descoberta e desenvolvimento de novos agentes. Química Nova, v.33, n.3, p.667-679, 2010.

KADOSAKI, L. L.; SOUSA, S. F.; BORGES, J. C. M.. Análise do uso e da resistência bacteriana aos antimicrobianos em nível hospitalar. Revista Brasileira de Farmácia, v.93, n.2, p.128135, 2012.

LEVISON, W.. Microbiologia médica e imunologia. 10 ed. Porto Alegre: Artmed, 2011.

LOUREIRO, R. J.; ROQUE, F.; RODRIGUES, A. T.; HERDEIRO, M. T.; RAMALHEIRA, E.. O uso de antibióticos e as resistências bacterianas: breves notas sobre a sua evolução. Revista Portuguesa de Saúde Pública, v.34, n.1, p.77-84, 2016.

MARTINS, A. F.; BARTH, A. L.. Acinetobacter multirresistente: um desafio para a saúde pública. Scientia Médica, Porto Alegre, v.23, n.1, p.56-62, 2013.

MORAES, A. L.; ARAUJO, N. G. P.; BRAGA, T. L. Automedicação: revisando a literatura sobre a resistência bacteriana aos antibióticos. Estácio Saúde, v.5, n.1, p.122132, 2016.
MOREIRA, N. M.; SOLA, M. C.; FEISTEL, J. C.; OLIVEIRA J. J.; FREITAS F. A.. O mecanismo de resistência bacteriana da salmonela sp. Frente à utilização de antibióticos. Centro Científico Conhecer, Goiânia, v.9, n.16, p.1131-1153, 2013.

MOTA, L. R.; LOPES, A. F.; NEVES, T.; RODRIGUES, T.; RAMOS, R.; COVITA, A.; SOARES, M. J.; MONTEIRO, P. G.; GANHOTO, A.; NOGUEIRA, R.; BARRETO, J. L.; MONTEIRO, H.. Infecção multirresistente em urologia. Acta urologia, n.1, p.21-26, 2012.

OLIVEIRA, A. L. D.; SOARES, M. M.; SANTOS, T. C. D.; SANTOS, A.. Mecanismo de resistência bacteriana a antibióticos na infecção urinaria. Uningá, v.20, n.3, p.65-71, 2014.

OLIVEIRA, K. R.; MUNARETTO, P.. Uso racional de antibióticos: responsabilidade de prescritores, usuários e dispensadores. Contexto e Saúde, v.9, n.18, p.43-51, 2010.

PAIM, R. S. P.; LORENZINI, E.. Estratégias para prevenção da resistência bacteriana: contribuições para segurança do paciente. Cuidarte, v.5, n.2, p.757-764, 2014.

RIBEIRO, J. L.; COMARELLA, L.. Bactérias multirresistentes e emergência da resistência tipo new delhi metallo- $\beta$ lactamase-1 (NDM-1). UNIANDRADE, v.16, n.2, p.109-118.

SILVA, C. F.; GEHLEN, S. S.; WEBBER, B.; DIEDRICH, L. N.; PILOTTO, F.; SANTOS, L. R.; TONDO, E. C.; NASCIMENTO, V. P.; RODRIGUES, L. B.. Salmonella enteritidis formadoras de biofilmes são multirresistentes a antimicrobianos. Acta Scientiae Veterinariae, v.42, 2014.

TORTORA, G. J.; FUNKE, B. R.; CASE, C. L.. Microbiologia. 10 ed. Porto Alegre: Artmed, 2012.

TRAVASSOS, I. O.; MIRANDA, K. C. V.. Resistência bacteriana como consequência do uso inadequado de antibióticos. Infarma, v.22, n.6, 2010.

VASCONCELOS, F. R.; REBOUÇAS, R. H., EVANGELISTABARRETO, N. S.; SOUSA, O. V.; VIEIRA, R. H. S. F.. Arquivos do Instituto de Biologia, São Paulo, v.77, n.3, p.405-410, 2010.

A CBPC - Companhia Brasileira de Produção Científica (CNPJ: 11.221.422/0001-03) detém os direitos materiais desta publicação. Os direitos referem-se à publicação do trabalho em qualquer parte do mundo, incluindo os direitos às renovações, expansões e disseminações da contribuição, bem como outros direitos subsidiários. Todos os trabalhos publicados eletronicamente poderão posteriormente ser publicados em coletâneas impressas sob coordenação da Sustenere Publishing, da Companhia Brasileira de Produção Científica e seus parceiros autorizados. Os (as) autores (as) preservam os direitos autorais, mas não têm permissão para a publicação da contribuição em outro meio, impresso ou digital, em português ou em tradução. 